\title{
ВИХОВАННЯ ДИТЯЧОГО СПІВАЦЬКОГО ГОЛОСУ В СИСТЕМІ ЗАГАЛЬНООСВІТНЬОЇ ТА МУЗИЧНОЇ ШКІЛ
}

\author{
Можайкіна Н. С.
}

\section{ВСТУП}

У сучасних умовах розвитку суспільства все більшої актуальності набувають питання естетичного виховання дітей та молоді. Одним 3 напрямів естетичного виховання можна назвати вокальну роботу в загальноосвітніх школах та закладах допоміжного навчання мистецького спрямування. Саме в зазначених установах та організаціях закладаються основи естетичного розвитку особистості. Провідну роль у вирішенні зазначеної проблеми відіграє музика, яка $\epsilon$ невіддільною частиною морального життя учнів.

Виховання дитячого співацького голосу є особливою і дуже важливою науковою і практичною проблемою. Це пов'язано з тим, що кількість дітей, які навчаються співу, значно більша, ніж кількість дорослих. Крім того, є велика кількість викладачів (вчителів, педагогів), які виконують навчальну функцію і водночас є мало обізнаними зі специфікою дитячого вокального виховання. Також варто зважати на те, що вокальні навички, сформовані у дитячому віці, є основою голосу майбутньої дорослої людини. Отже, роль вчителя вокалу (постановки голосу) або керівника хорового колективу є надзвичайно важливою та відповідальною.

Дитяча вокальна педагогіка має низку своїх особливостей, які відрізняють іiі від вокального навчального процесу із дорослими. Ці особливості пов'язані з тим, що дитячий організм ще несформований i знаходиться в певній стадії свого анатомо-фізіологічного розвитку. Це період накопичення організмом необхідних фізичних сил, а також знань, вмінь і навичок. Важливо підкреслити, що зростаючий організм є ще дуже слабким i нездатним виконувати великі навантаження, які $\epsilon$ можливими для дорослої людини.

Окреслене вище дає підстави для розгляду наступних питань: вікові особливості розвитку дитячого голосу; акустичні властивості дитячого вокального мовлення, а також визначення шляхів виправлення основних недоліків звукоутворення.

\section{1. Вікові особливості розвитку дитячого голосу}

Протягом шкільного періоду голос учня (учениці) проходить декілька вікових стадій розвитку. Ці стадії пов'язані із статевим формуванням, 
фізичним та нервово-психічним зростанням дитини, особливостями будови резонаторної системи голосового тракту та дихальної функції.

Голос дитини у віці 7-8 років знаходиться ще в самій початковій стадії розвитку. Гортань та голосові м'язи в цьому віці дуже слабкі, до кінця не сформовані.

Голосовий м'яз, який знаходиться в товщі голосової складки, починає розвиватися тільки 3 7-8-річного віку. Звук, який зароджується в гортані, утворюється під час крайового коливання голосових зв'язок, що й зумовлює так зване фальцетне звучання. Розвиток відбувається майже однаково як у дівчат, так і у хлопців.

Голос дитини в цьому віці ніжний, невеликий за силою, має високе звучання. Робочий діапазон зображено на рис. 1.

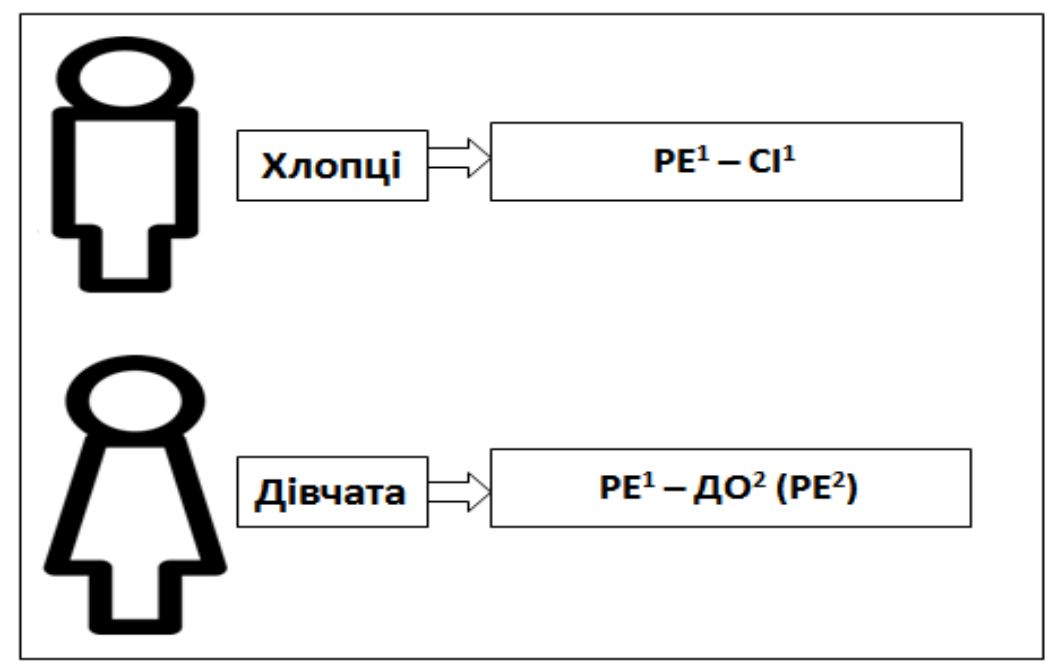

\section{Рис. 1. Робочий діапазон хлопців і дівчат 7-8 років}

У 9-10 років, коли зростає вокальний м'яз, починається формування дитячого голосу. У низьких голосів 3'являється участь у фонації середніх ділянок глосових зв'язок, до фальцетного звучання додається мікстове. Голоси вже можна розділити на більш високі і низькі (хлопці дисканти та альти, дівчата - сопрано та альти). Закономірним у цьому віці $є$ головне звучання - залучення до резонування верхнього головного резонатора, що надає голосу особливої дзвінкості та польотності. Дзвінкість у цьому віці компенсує відсутність сили голосу, якої не слід вимагати, оскільки це суперечить анатомо-фізіологічним властивостям дитячої гортані. Робочий діапазон в 9-10 років зображено на рис. 2.

Якщо заняття в хорі добре організовані вчителем, і співацьке виховання йде правильно, то голос звучить особливо красиво. У хлопців голос набуває особливої дзвінкості, сріблястості, а в голосах дівчат спостерігається вже індивідуальне темброве забарвлення. 


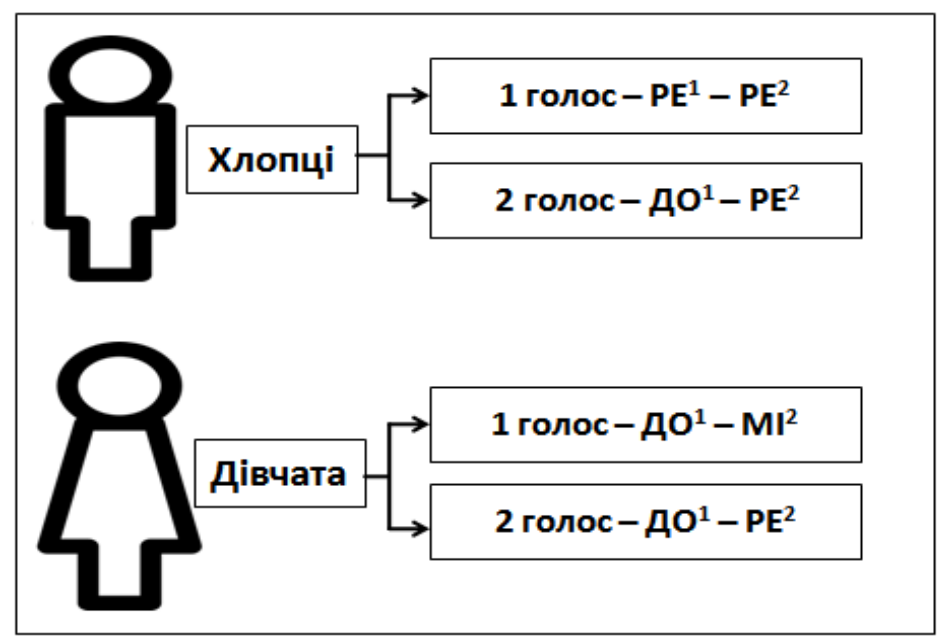

Рис. 2. Робочий діапазон хлопців і дівчат 9-10 років

Вчителю потрібно пам'ятати, що до 10-11 років оформляється нервовом'язова система голосового апарату. В гортані розвивається надзвичайно важливий м'яз - голосовий. Його будова поступово ускладнюється і він починає керувати всією роботою голосових зв'язок, які стають пружними. Коливання зв'язок перестає бути крайовим, воно розповсюджується на всю довжину голосової складки, і голос стає сильним, компактним, стійким, набуває тембрових та індивідуальних забарвлень.

У майбутніх альтів голос розширюється до низу діапазону, у високих голосів - до верху (рис. 3). Верхні звуки починають звучати міцніше і стійкіше, а нижні - набувають більшої польотності та звучності. Міцнішає та значно розвивається дихальна система, нервова система та дитяча психіка.

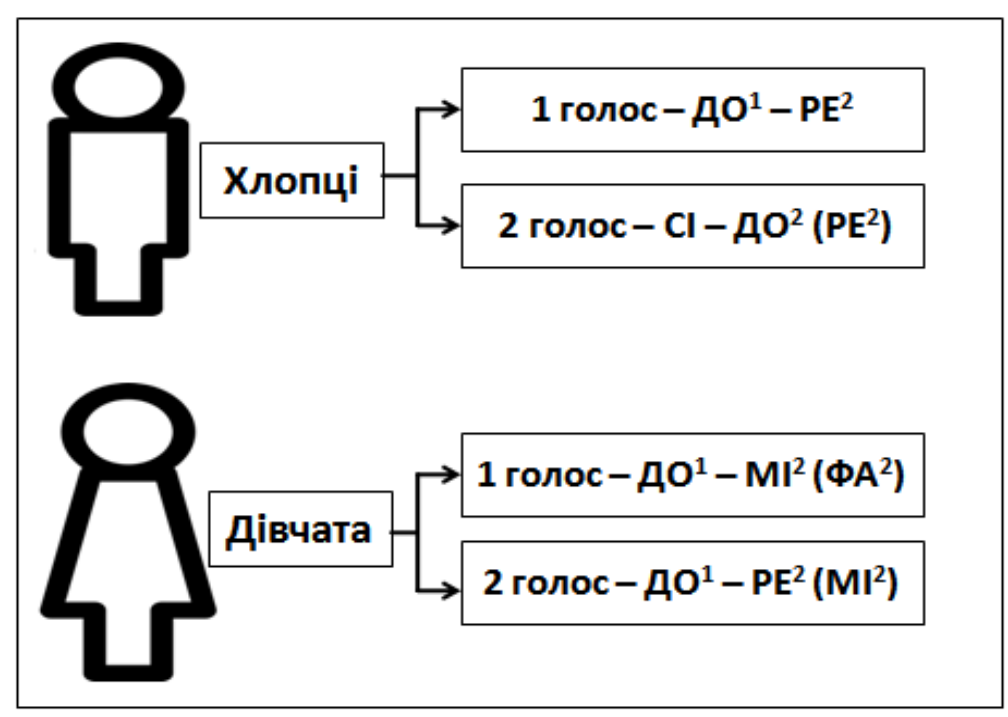

Рис. 3. Робочий діапазон хлопців і дівчат 10-11 років 
Потрібно знати, що вже в 11-12 років 3'являються перші ознаки, які вказують на зміни, що відбуваються в організмі. Фізичне зростання учнів та, зокрема, зростання голосового апарату перестає бути плавним. Розвиток відбувається нерівномірно. Настає передмутаційний період. Внаслідок росту голосових зв'язок в довжину діти важко справляються 3 верхніми звуками свого діапазону, голос втрачає яскравість, ніби тьмяніє, трохи сипить; спостерігається почервоніння голосових зв'язок, набряклість, млявість, роздратованість (рис. 4). Варто пам'ятати, що всі ці зміни можуть негативно вплинути на співацький голос, якщо не буде відповідного розуміння та спеціального режиму.

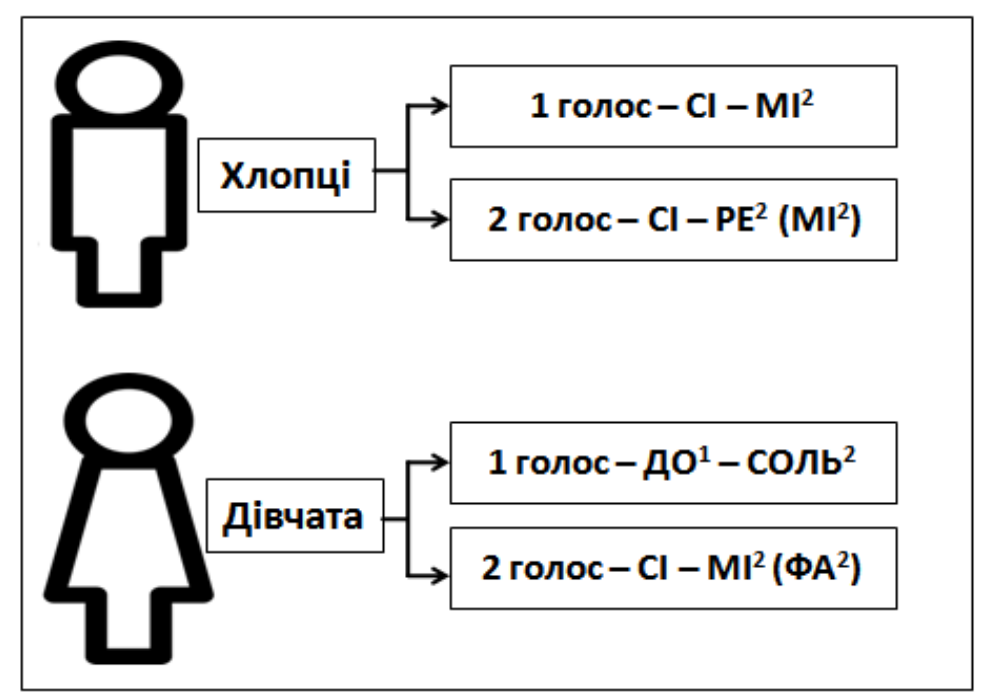

Рис. 4. Робочий діапазон хлопців і дівчат 11-12 років

Варто враховувати, що в практиці можуть спостерігатися різні форми мутації. Вона може бути ранньою або пізньою, коли зміна в голосі починається не як зазвичай, в 13-14 років, а в 16-17. Це явище пов'язано із затримкою загального розвитку організму, розладами функції ендокринних залоз.

Зазвичай мутаційний період завершується в 16-17 років. У тембрі хлопців та дівчат з'являється відтінок майбутнього дорослого голосу, його сила тільки починає наближуватися до сили дорослого голосу. Наступає післямутаційний період. $\mathrm{У}$ цей період ще можуть спостерігатися залишкові явища мутації, коли зростання гортані відстає від зростання грудної клітини, і виходить невідповідність у роботі дихання і голосових зв'язок, м'язова сила яких ще недостатньо зміцніла і потребує відповідного режиму. Остаточне формування голосу відбувається лише до 20 років, коли вже сформований увесь організм.

Вчитель музики загальноосвітньої школи або вчитель вокалу (хорового класу) музичних шкіл ні в якому разі не повинні забувати, що 
дитячий голосовий апарат сильно відрізняється від голосового апарату дорослої людини. Його механізм ще є простим за своєю структурою. Він дуже тендітний, ніжний, безперервно зростає, змінюється та надмірне напруження може завадити його нормальному зростанню. Дитячий голосовий апарат повинен розвиватися у повній відповідності до розвитку усього організму дитини. Відповідно, голос дітей ще не має тої сили, яка з'явиться поступово 3 розвитком вокальних м'язів. Тому займатися 3 дітьми вокалом потрібно обережно, сприяючи розвитку голосового апарату та загальному розвитку дітей, а відтак і репертуар потрібно підбирати для них з огляду на вік.

Заняття потрібно розпочинати із зручних для голосу розспівок, під час яких відбувається поступова підготовка голосового апарату до правильного звучання. Кожна вправа спочатку співається так, як записано, а потім від інших звуків: вище та нижче. На рис. 5 представлено приклади вправ.

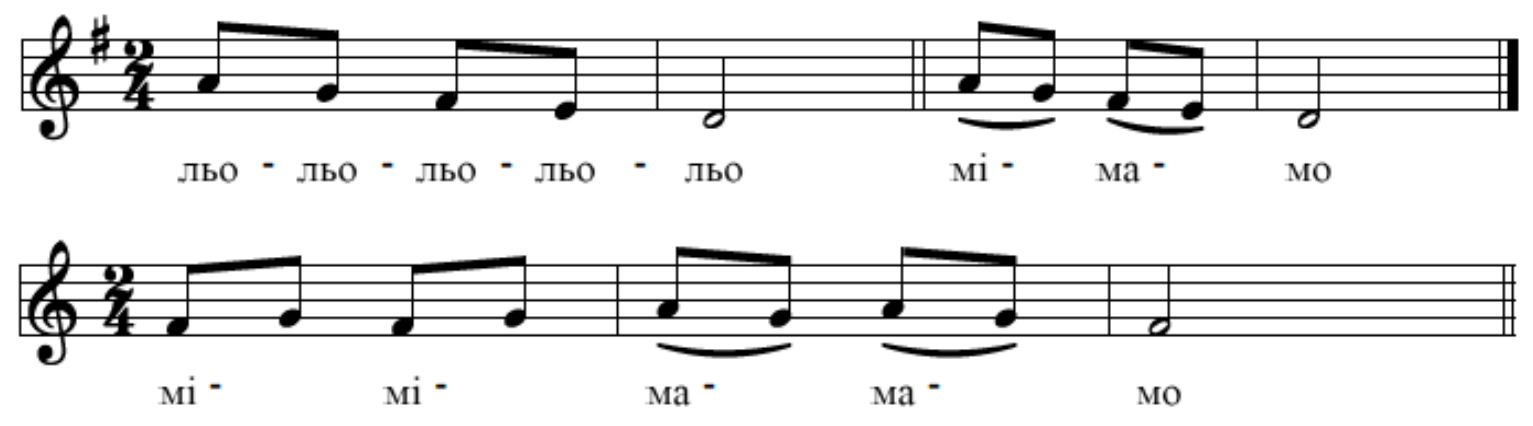

Рис. 5. Вправи на розспівування

Для розспівування також можна використовувати пісні або їх уривки, передбачені відповідними шкільними програмами. Найкраще використовувати народні пісні.

Під час розспівування вчителю варто тримати під контролем фонацію звуку, роботу артикуляційного апарату, роботу дихання тощо. Для контролю над звуком вчителю потрібне чітке розуміння про те, як працюють органи, які беруть участь у голосоутворенні, який звук має бути за умови правильної роботи усіх органів. Маючи такі уявлення, вчитель зможе правильно оцінювати звучання одного учня, а також цілого колективу (ансамблю, хору), свідомо та об'єктивно виправляти недоліки у співі учнів. Такої ж думки дотримується й В. Черкасов, який у своєму дослідженні зазначає, що кожну вправу учні мають сприймати як музичну мініатюру й виконувати виразно та усвідомлено. Для цього вчитель повинен обгрунтувати іiі мету, проілюструвати й пояснити методику та вимоги щодо іiі відтворення. Автор висновує, що вправи виконуються у вигляді модулюючих секвенцій по півтонах у висхідному 
та низхідному напрямах. На початковому етапі мелодію необхідно підтримувати інструментальним супроводом. Для вдосконалення вокально-хорових навичок вокальні вправи доцільно співати без інструментального супроводу з попередньою ладовою настройкою ${ }^{1}$.

Найскладнішою частиною голосового апарату є гортань 3 голосовими зв'язками, яка у дітей у 2-2,5 разів менше, ніж у дорослих.

Необхідно пам'ятати, що гортань - це тендітний, дуже вразливий у разі неправильного функціонування апарат, який розташований над трахеєю у передньому відділенні шиї та складається із складної системи хрящів. Між ними протягнені дві голосові зв'язки, які разом 3 розташованими поряд голосовими м'язами вкриті слизовою оболонкою та утворюють голосові складки гортані. Права та ліва голосові складки обмежують голосову щілину.

Звук, який зароджується в гортані, утворюється в процесі періодичних скорочень голосових зв'язок під час їх змикання і розмикання, коли переривається потік повітря, що проходить через них. Голосові зв'язки починають рухатися завдяки внутрішнім м'язам, що знаходяться у товщі складок, розташованих на хрящах. У цей момент утворюються звукові коливання, які потім перетворюються на мовлення та спів.

Крім особливостей, характерних для кожного вікового періоду, є й загальні закономірності в роботі співацького механізму, притаманні усім. Тому, починаючи перші заняття 3 дітьми, потрібно зосередити увагу на співацькому диханні, атаці звуку, артикуляції.

У момент, коли учень (учениця) повинен заспівати, його видих робиться більш енергійним, повітря під зв'язками ущільнюється та тисне на них. Самі голосові зв'язки напружуються. Здійснюючи опір тиску повітря, що видихається, вони починають коливатися, тобто розмикатися і змикатися, утворюючи звук. Момент утворення звуку називається початком звуку, або атакою.

Варто звернути увагу, що $є$ три види атаки: тверда, м'яка та придихова. Під час навчання дітей співу використовується тверда та м'яка атаки. Під час спокійного, звичного дихання голосові зв'язки розімкнені. Перед початком звуку вони змикаються. Під час твердої атаки вони змикаються щільно, здійснюючи опір сильно ущільненому повітрю, який накопичився під ними. Звук виходить твердий, енергійний. Тверда атака сприяє укріпленню голосу. За загальної млявості слід розвивати активність, виховувати бадьорість, укріплювати голосовий апарат, даючи вправи до твору із застосуванням твердої атаки. Такої ж думки дотримуються українські вчені I. Липа та

\footnotetext{
1 Черкасов В. Вокально-хорова робота на уроках музичного мистецтва як засіб формування естетичної культури учнів загальноосвітніх навчальних закладів. Наукові записки ГКіровоградського держсавного педагогічного університету імені Володимира Винниченка]. Сер.: Педагогічні науки. 2012. Вип. 103. С. 11.
} 
О. Черсак, які зазначають, що процес формування м'якої атаки звука може дещо ускладнитися через схильність деяких дітей до в'ялої, інертної подачі звука. У них м'яка атака часто призводить до значного витоку повітря під час співу і поганого звукоутворення. Автори висновують, що у таких учнів слід активізувати голосоутворення, використовуючи тверду атаку. При цьому виді атаки голосова щілина змикається достатньо щільно ще до початку звукоутворення і потім із силою проривається потоком повітря, що видихається. I. Липа та О. Черсак наголошують, що тверда атака забезпечує інтенсивну роботу голосового апарату, а миттєвість початку звука допомагає точності інтонування ${ }^{2}$.

Водночас вчителю не варто забувати, що тверда атака звуку не може використовуватись як постійний прийом голосоутворення. Вона дезорганізує діяльність гортані, призводить до форсованого співу, за якого голосові зв'язки не м'яко зближуються, а накладаються одна на одну, перезмикаються, і від постійного тертя на них з'являються «співацькі вузли», які потім важко вилікувати.

Таким чином, можна висновувати, що тверду атаку можна використовувати на заняттях тільки як певний спосіб виразності, якщо зміст пісні вимагає енергійного звучання, активного подання дихання.

Для нормального вокального виховання дітей рекомендовано використовувати м'яку атаку звуку, за якої голосові зв'язки змикаються менш щільно, чинячи опір менш ущільненому повітрю під ними. Звучання виходить м'яким, дзвінким, без акцентів. За м'якої атаки можна досягти дуже тонких художніх відтінків. На переконання Р.Г. Шаповалової, м'яка атака звуку - це не розслаблене і в'яле звукоутворення, а навпаки, активний, але дуже тихий, інтонаційно точний й обережний дотик до звуку, який потім одразу ж наповнюється енергією, як при швидкому посиленні звуку. Автор зазначає, що за такого біомеханізму фонації голосові складки відіграють пасивну роль. Їхні рухи підпорядковані законам аеродинаміки; мускулатура складок бере участь у фонації лише завдяки своїй еластичності і тонусу, а не активним розміреним рухам ${ }^{3}$.

Звернемо увагу на третій вид атаки - придиховий. Придихова атака буває у разів неповного змикання зв'язок, тобто під час сильного витікання повітря. Така атака зустрічається у дітей з хворим голосовим апаратом. У цьому разі у зв'язку з появою вузлів або потовщенням (нерівностям) на зв'язках вони не можуть змикатися. Такий стан

\footnotetext{
2 Липа І., Черсак О. Підготовка майбутнього вчителя до педагогічного керівництва співацьким розвитком молодших школярів. Збірник науково-методичних праць кафедри педагогіки початкової освіти Педагогічного факультету Прикарпатського наџіонального університету імені Василя Стефаника. 2019. Вип. 3. С. 12.

${ }^{3}$ Шаповалова Р.Г. Навчання сольному співу: голосоутворення та його структурні компоненти. Освітологічний дискурс. 2015. № 1 (9). С. 243.
} 
можливий також у разі запальних процесів гортані, загальної млявості дитини, дуже слабкого видиху.

Голос дітей знаходиться в недостатньо розвиненому стані не лише у зв'язку з тим, що вокальні м'язи у них ще слабкі, і голосові зв'язки змикаються не щільно, а й у результаті недостатнього розвитку дихальних м'язів, нездатних здійснювати подачу великої сили голосу.

Виховання правильного співацького дихання - один із складних процесів під час навчання співу. Від дихання залежить зародження звуку, сила і тривалість звучання, енергія. Без нього не буде мовлення, не буде й пісні. Щоб навчитися співати, потрібно допомогти учню оволодіти своїм диханням, навчити ним користуватися, тому що співацьке дихання відрізняється від звичайного, життєвого.

Нагадаємо, що у співі існують наступні типи дихання: ключичне, грудне, нижньореберно-діафрагмальне, брюшне. Найбільш доцільним для співу є нижньореберно-діафрагмальне дихання.

Співацьке дихання розвивається повільно разом з розвитком усього організму. В роботі з учнями варто користуватися такими необхідними принципами дихання: спокійний, помірний глибокий вдих, невелика затримка перед початком звуку, плавна подача дихання і вміння його розподілити.

Головна складність навчання дітей співацькому диханню полягає в особливому педагогічному підході до цього навчання, який враховує дитячу психіку та рівень дитячого розуміння.

На перших етапах вчителю потрібно привчати учнів до основних прийомів дихання, однак вказівки про правильне дихання дітям потрібно давати дуже обережно і поступово, суто практично, не вдаючись до будь-яких фізіологічних та анатомічних пояснення. Вчитель сам може показати швидкий і мінімальний вдих за вільного стану грудної клітини, зазначивши, для наочності, про схожість вдиху з тими рухами, які виникають під час раптового переляку або радості, коли ми коротко вимовляємо «ах», швидко втягуючи повітря. Ці рухи і відчуття настільки доступні розумінню дитини, що повторити їх буде не важко. Потрібно, щоб діти з перших уроків засвоїли, що саме важливе у співі полягає не в тому, щоб набрати велику кількість повітря, а у тому, щоб витрачати його повільно, стримано і поступово. Автори Л.Г. Ятло та Л.П. Ятло також зазначають, що під час вдиху не потрібно брати дуже багато повітря в легені, оскільки воно давить своїм надлишком на зв'язки, примушує відразу ж робити видих, зумовлює нечисту інтонацію. Як залишки повітря, що видихається, так і його нестача однаково шкідливі, бо впливають на якість звуку. Майже в усіх випадках фальшиве, занижене звучання хору $є$ наслідком слабкого дихання, і навпаки, 
підвищення інтонації, крикливість, це результат напруженого, форсованого видиху ${ }^{4}$.

Враховуючи невелику ємність дитячих легень, вчитель повинен працювати над раціональним розподілом дихання у вправах та вокальних творах. Протяжні, повільні, кантиленні пісні у разі їх продуманого підбору (маючи на увазі поступовий розвиток та зміцнення дихання) та правильної організації в них дихання $\epsilon$ чудовими у вихованні співацького голосу.

Розвиток співацького дихання у дітей можна розділити на вікові етапи. У молодших класах переважає грудний тип дихання. Із розвитком дихальних м'язів дитяче співацьке дихання стає глибшим і стійкішим, наближуючись до нижньореберно-діафрагмального дихання. Навчання правильному співацькому диханню на кожному віковому етапі повністю залежить від росту усього організму: грудної клітини в іiі окружності, дихальної мускулатури, ємності легень, розвитку та зміцнення його нервово-м'язових сил.

Одночасно з диханням розвивається й артикуляція. Під артикуляцією розуміємо роботу органів вимови: нижньої щелепи, губ, язика, м'якого піднебіння, глотки. Результатом оволодіння артикуляцією $є$ чітка дикція, тобто чітка вимова, коли спів стає виразним, а вокальний твір зрозумілим.

Слід врахувати, що артикуляційний апарат у дітей часто буває млявим; у них малорухлива, напружена нижня щелепа (особливо у хлопців), мляві губи та малорухливий язик. Діти часом погано i неправильно відкривають рот. Всі зазначені недоліки позначаються на мовленні та співі. Порожнина рота - основний резонатор, тобто орган, який формує голосні і приголосні та сильно впливає на забарвлення звуку (тембр). Звільнити від напруження нижню щелепу (уникаючи в той же час надмірно великих іiі рухів), навчити правильно відкривати рота, активно працювати під час вимови губами, тримати язик у роті вільно - це основні завдання під час навчання дітей співацької дикції, вимови у співі. Для досягнення гарної дикції рекомендується співати голосні у поєднанні з губними приголосними «Б», «П», «М», які активізують роботу губ, допомагають енергійніше вимовляти голосні.

Водночас для відпрацювання єдиного вокального звучання різних голосних рекомендуємо використовувати вправу, зображену на рис. 6.

Для формування правильної та якісної вимови голосної «А» потрібна вільна нижня щелепа. Для іiі розслаблення потрібно виконувати вправи на склади: «Дай», «Май», «Бай», розспівування яких необхідно починати із середини співацького діапазону, в межах примарних тонів.

\footnotetext{
${ }^{4}$ Ятло Л.Г., Ятло Л.П. Сівацьке дихання як основа вокально-хорової техніки дитячого хору. Збірник наукових праџь Уманського державного педагогічного університету. 2007. № 2. URL: http://znp.udpu.edu.ua/article/view/187651.

296
} 


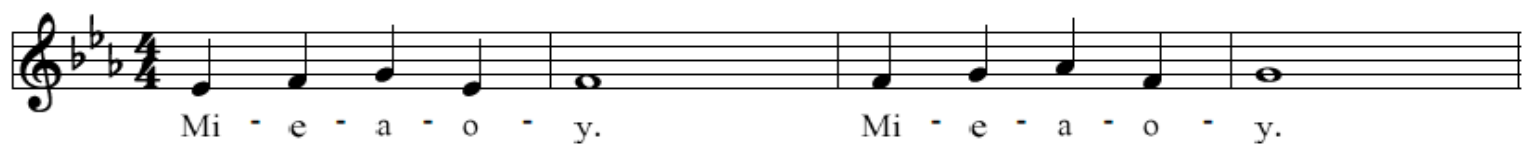

5

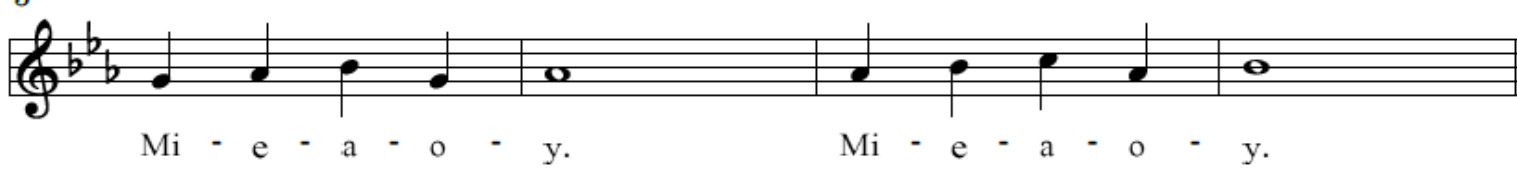

9
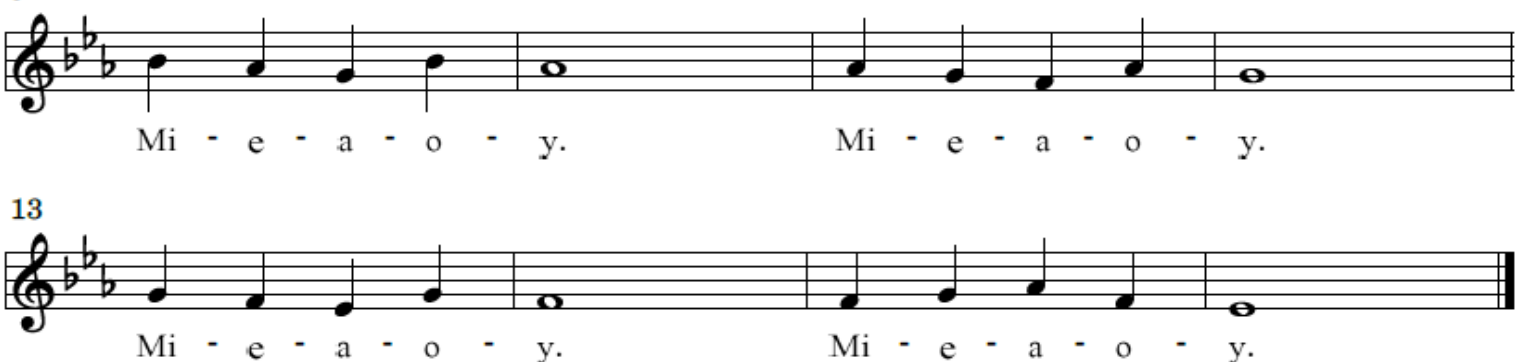

Рис. 6. Вправа для формування сдиного вокального звучання голосних

Вчитель повинен знати, що під час виконання голосної «І» дещо розширюється овал рота, середня частина язика піднімається трохи вгору. Спів на голосу «І» сприяе відпрацюванню в дитячому голосі високого звучання та дзвінкості. Однак співом на цю голосну не потрібно зловживати, щоб не отримати надмірно різкий, беззмістовний звук. Рекомендуємо голосну «I» співати у поєднанні (чергуючи) з «А» або «Я».

Під час співу голосної «О» губи дещо випинаються, і рот набуває подовженої, округлої форми. Його потрібно відкрити більше. В той же час голосна «У» зближує губи більше, ніж «О». Губи трохи витягуються вперед. Спів голосних «О» та «У» округляє, прикриває звучання високих нот. Сильно витягувати губи на зазначені голосні не потрібно, оскільки це приглушає звук.

Таким чином, можемо сформулювати особливості вимови у співі: 1) співучість голосних; 2) вміння їх округляти; 3) за можливості, чисте звучання ненаголошених голосних; 4) швидке і чітке вимовляння приголосних на висоті наступних за ними голосних; 5) перенесення приголосних з кінця складу на початок наступного складу (перенесення приголосної з кінця слова на початок наступного слова під час злиття двох приголосних (яскрави/м/_мсон-цем). Цей прийом можливий тільки на legato, на staccato вимовляється так, як і пишеться - відокремлюючи.

Аналізуючи причини поганої дикції у дітей, вчитель з'ясовує, за рахунок яких голосних та приголосних відбуваються дефекти дикції, особливу увагу приділяючи вимові приголосних у співі.

Чому ж приголосні так сильно впливають на дикцію? Частково це пояснюється тим, що приголосних в українській мові значно більше, ніж 
голосних. Приголосні поділяють мовленнєвий потік на склади та забезпечують розбірливість цих складів. Якість дикції залежить також від віку дитини, яка співає (чим старша дитина, тим краще дикція), від ступеню розвитку співацького дихання, від ступеня свободи голосового апарату під час співу, від висоти ноти (чим вище звук, тим гірше зрозумілість 3 тої причини, що високі звуки вимагають значно більшого напруження і пристосування голосового апарату). У разі співпадіння високого звуку 3 низькочастотною голосною «У» створюються несприятливі акустичні умови для розбірливості (зрозумілості); помітне погіршення розбірливості на самих низьких звуках діапазону під час перехідних нота. Крім того, розбірливість залежить від індивідуальності учня, від типу його голосу, майстерності, рівню проникнення в образ вокального твору, емоційного налаштування тощо.

\section{2. Акустичні властивості дитячого вокального мовлення.}

\section{Шляхи виправлення основних недоліків звукоутворення}

В основі виховання голосу дітей знаходиться робота над якістю звучання. Для цього вчитель повинен мати свої слухові уявлення щодо зразків звучання дитячого голосу, обов'язковою умовою розвитку якого $\epsilon$ виховання дзвінкого, сріблястого, ніжного звучання. Таким чином, потрібно знати також акустичні властивості вокального мовлення дітей (рис. 7).

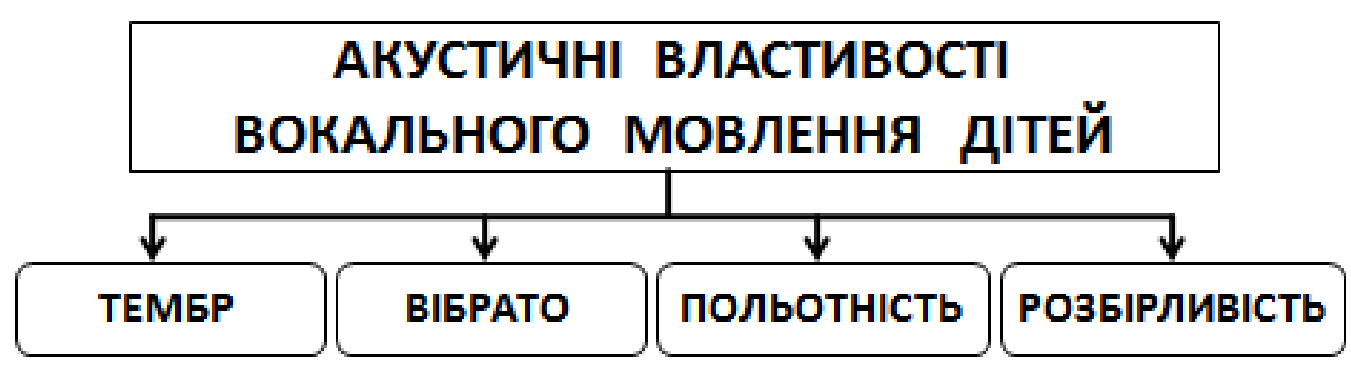

Рис. 7. Акустичні властивості голосу

Тембр є важливою властивістю, яка складає головне багатство голосу, його забарвлення. За тембром вчитель визначає тип голосу учня (сопрано, альт, дискант тощо). Як відомо, звуки мовлення складаються 3 основного тону та численних обертонів, тобто звуків іншої, ніж основний тон, частоти, які знаходяться в чіткому співвідношенні з ним. Висота звуку визначається частотою основного тону, а тембр - наявністю тих або інших обертонів. Група високих обертонів, яка визначає польотність та дзвінкість голосу, називається високою співацькою формантою.

Тембр голосу виконавця визначається також характером вібрато співацького голосу - це періодичні зміни частоти сили звуку, ніби 
ритмічна плавна пульсація 3 частотою приблизно 5-7 пульсацій на секунду, яка сприймається найбільш милозвучно. Ця пульсація робить голос живим, піднесеним, впевненим, емоційним, виразним. Надмірно часта пульсація, тобто велике вібрато, сприймається як «баранчик» в голосі, а рідка - як качання голосу. 3 огляду на таке дослідження цікавою є думка Ю.М. Данільчишина, який зазначає, що вібрація у звуці співочого голосу залежить від періодичної зміни всіх характеристик звуку: висоти, сили та тембру, пульсуючих з однаковою частотою. Якщо грамофонну платівку або магнітофонний запис співочого голосу прослухати на вдвічі уповільненій швидкості, то можна легко почути вібрато. Голос звучатиме на октаву нижче. Його тембр зміниться, а обертони змістяться на октаву нижче, і чітко простежуватиметься вібрато висоти. Автор висновує, що голос у процесі вібрато зазвичай змінюється за висотою на $1 / 2$ тону, іноді й більше, тобто вібрує навколо середньої частоти, яку сприймаємо як основний тон 5 .

Вчителю потрібно пам'ятати, що вібрато відіграє надзвичайно важливу роль в утворенні співацького голосу, збільшує його звучність, польотність, стійкість до перешкод. Вібрато в голосі дітей молодшого віку відсутнє, а в учнів 12-15 років стає вже помітним, але позначається не на всіх голосних i не має ще чіткої періодичної пульсації. В період мутації у хлопців вібрато не фіксується, у дівчат 16-17 років - вже добре помітне.

Для появи вібрато до моменту сформованості дорослого голосу потрібно приділяти особливу увагу його розвитку вже в дитячому віці.

Працюючи з дітьми, вчитель повинен знати, що характер вібрато залежить від будови голосового апарату, від стану нервової системи особи, а також від набутих навичок, спрямоване виховання яких дозволяє, як й інші властивості голосу, позитивно впливати на утворення вібрато.

Такої ж думки дотримується О.М. Прядко, яка зазначає, що без спеціальних вправлянь вібрато у дітей нормалізується після мутації, в період післямутаційного розвитку. Тому, на думку автора, саме в період становлення дорослого голосу вокаліста виробленню красивого вібрато має надаватися особлива увага. За умови тривалої систематичної роботи педагога та учнів під час навчання вібрато може удосконалюватись, набувати естетичної частоти вібрації. Голоси, позбавлені вібрато, сприймаються як «прямі», «нецікаві», позбавлені життєвої енергії. Вібрато сприймається як прикраса співацького звуку, хоча, по суті, $\epsilon$ чергуванням сили та висоти. Воно має властивість приховувати деяку інтонаційну неточність під час співу та нерівність звучання голосу6

\footnotetext{
5 Данільчишин Ю.М. Акустика голосового апарату й акустична будова голосу. Культура Украӥни. 2014. Вип. 46. С. 279.

${ }^{6}$ Прядко О.М. Акустичні особливості розвитку співацького голосу. Педагогічні науки: теорія, історія, інноваційні технологї. 2010. № 7 (9).С. 407.
} 
Однією 3 центральних проблем у сучасній вокально-педагогічній практиці $\epsilon$ проблема польотності співацького голосу, тобто його здатність розповсюджуватися на великі відстані, виділятися на фоні інших звуків. Польотність залежить від рівня дзвінкості, висоти голосу, рівня вираженості вібрато в голосі.

Цікавою є думка В.Т. Бордуліна та Ж.В. Штепи, які зазначають, що співучість, «польотність» вокального звуку - це одна із якісних характеристик вокального звуку. Таким звуком можна співати і нелегатовані, стаккатовані звуки. Кантилена як засіб художньої виразності $\epsilon$ найхарактернішим моментом виявлення співучості. Принцип кантиленного співу полягає в тому, що техніка побудови кожного наступного звуку має відповідати техніці побудови попереднього. Звук, на переконання авторів, має бути абсолютно рівним, однорідним та однаково якісним ${ }^{7}$.

Польотність $є$ важливою властивістю співацького голосу, яка особливо цінується на професійній сцені. Голоси як дорослих, так i дітей, які мають низький коефіцієнт польотності, на слух сприймаються як глухі, недзвінкі, позбавлені блиску, і навпаки, голоси, які мають високий коефіцієнт польотності, сприймаються як дзвінкі, сріблясті, чисті, яскраві. Неоднаковою польотністю характеризуються й різні голосні, тому вчителю необхідно прагнути в своїй роботі до вирівнювання голосних, щоб вони були однаково дзвінкими $\mathrm{i}$ польотними, щоб були вирівняні регістри голосу, щоб звукоутворення було вільним і невимушеним.

Велике значення для досягнення гарної польотності голосу має чіткість дикції, а також позитивний емоційний стан співака, який сприяє і більшій виразності співу.

Оскільки спів поєднаний зі словом, змістовним наповненням тексту, чого немає в інструментальній музиці, емоційний та ідейний його вплив на слухача значно зростає. Якщо у співака чудовий голос, але погана дикція, то художні переваги його співу для слухача значно втрачаються. Відтак можна стверджувати, що в одночасному забезпеченні гарної співацької кантилени та чудової дикції приховується одна із самих сокровенних таємниць вокального мистецтва.

Вчителю потрібно пам'ятати про певні обмеження, які накладають на голосову функцію дитини його вік. Сила голосу, звуковисотний та динамічний діапазон, формантний склад у дітей значно обмежені.

На жаль, дуже часто вчителі музики не знайомі 3 акустичними властивостями вокального мовлення, 3 природою дитячого і підліткового голосу, через що звучання дитячих голосів є слабким, що пов'язане з їх

\footnotetext{
${ }^{7}$ Бордулін В.Т., Штепа Ж.В. Основи вокальної майстерності. Сучасні інформаційні технологї̈ та інновачійні методики навчання в підготовці фахівиів: методологія, теорія, досвід, проблеми. 2012. № 30. С. 307.
} 
віком. Таке звучання часто не задовольняє вчителя, і він вимагає, щоб учень (учениця) співав голосніше. Неправильно спрямована вимогливість, вимогливість без меж, так само як і неуважність, безконтрольність, призводять до помилок, які важко потім виправляти і які породжують недоліки звукоутворення.

Відтак є необхідність визначити основні недоліки звукоутворення (рис. 8).

Працюючи 3 дитячими голосами, вчитель повинен вміти визначати кожен недолік звукоутворення окремо, причину його появи, а також володіти методами його виправлення.

У межах цього дослідження охарактеризуємо кожен із зазначених недоліків.

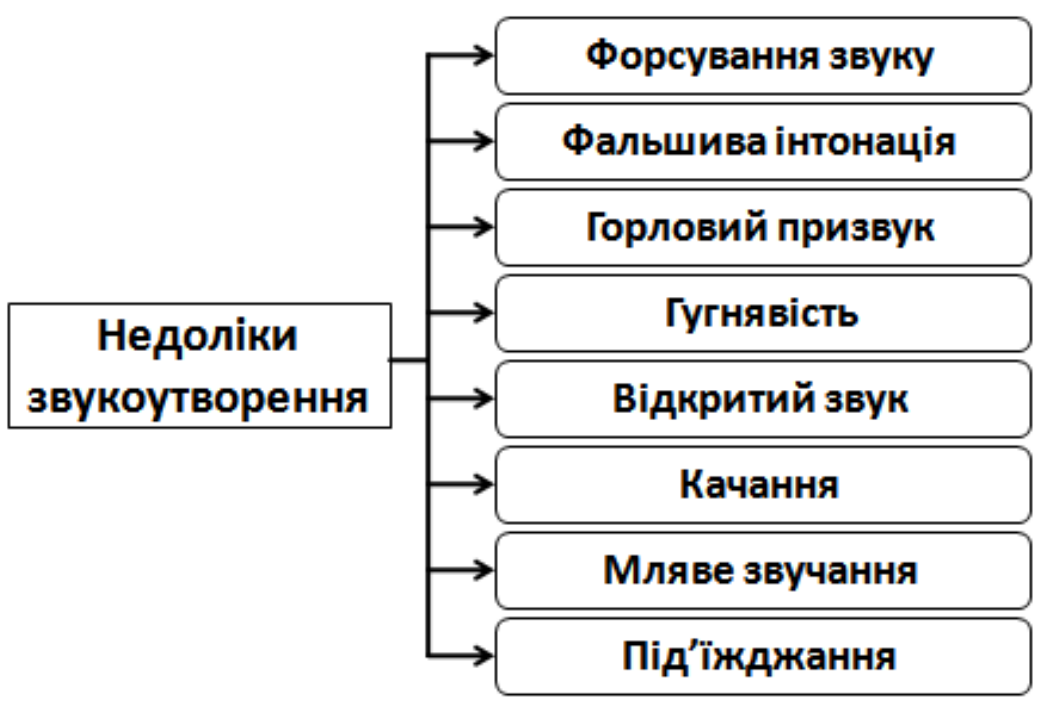

Рис. 8. Недоліки звукоутворення

Форсування $є$ запеклим ворогом вокального розвитку незміцнілого дитячого голосу, яке призводить до втрати вокальних здібностей, особливо в післямутаційний період.

Цей недолік часто є притаманним як окремим виконавцям, так i хоровим колективам, коли керівники вимагають співати голосніше, намагаючись надати голосу невластивої йому сили. При цьому голосовий апарат працює 3 істотним перенапруженням, надмірною силою звуку для цього віку. Використання крайніх нюансів або твердої атаки також може викликати порушення чистоти інтонації і різке зниження діапазону незміцнілого дитячого голосу.

Вчитель не повинен забувати, що голосовий апарат дітей відрізняється тендітністю та відсутністю стійкості до перевантаження в тій чи іншій формі. Під час форсування сили звуку голосовий апарат втрачає здатність 
формувати звук, який наповнений високою співацькою формантою. Голосові зв'язки починають працювати, виходячи із завдання співати голосніше, а не із намагання дати звук найбільшої краси.

У дітей у певному віці легке звучання здійснюється за незначної участі голосового м'язу, який у них ще погано розвинутий. Під час форсування не включається грудний, не властивий цьому віку механізм, що втомлює голосовий апарат і надає голосу напруженого, крикливого характеру.

У вокальній педагогіці є думка про важливість емоційних факторів у розвитку співацьких здібностей. Позитивний емоційний стан співака покращує дикцію, вібрато, дзвінкість та польотність голосу. Але при цьому не потрібно забувати, що на фоні емоційного збудження сприятливим підгрунтям $\epsilon$ форсування, від якого потрібно захистити голос співака. Це не означає, що дитячий спів повинен бути позбавлений будь-якої емоційності. Емоційність виконання необхідна, але вона також повинна відповідати можливостям дитини.

Часто діти намагаються наслідувати голоси дорослих співаків, імітуючи тембр, манеру співу, і змагаються у силі голосу з дорослими, знову ж таки включаючи грудний, не властивий цьому віку механізм, у результаті чого темброві якості поступово знижуються. Голос розгойдується, починає тремолювати, руйнується, тріщить, рівень високої співацької форманти зменшується.

Для усунення цього недоліку слід наполегливо працювати над якістю співацького тону, виключивши на певний час все, що може підштовхувати співака до форсованого звучання. Зняти зайву напругу потрібно на вправах, а пізніше на правильно підібраному репертуарі. Дієвим засобом для зняття форсування $є$ переведення співака або хорового колективу на м'яку атаку. Сила звуку може бути максимально $m f$. Зазначений прийом, а також спів із закритим ротом знімуть форсування.

Фальшива інтонація (детонування) виявляється по-різному: іноді це підвищення, іноді пониження інтонації. Породжують іiі різноманітні причини. Наприклад: захворювання голосового або слухового апарату, відсутність координації між слухом та голосом, антимузикальність, млявість або перевантажене дихання, неправильне формування звуку, низька його позиція, форсування, млява подача звуку, недбалість, відсутність музичного досвіду, результати неправильно проведених музичних занять. Причиною фальші у співі може слугувати також фізична слабкість, перевтома, мутація.

Вчителю передусім необхідно з'ясувати причини фальшивої інтонації. Якщо вона пов'язана 3 загальним станом організму або ж самим голосовим апаратом, співак повинен звернутися за медичною допомогою. Всі інші причини, крім природної відсутності музикальності, можна виправити у процесі навчання. 
Для усунення фальшивої інтонації потрібно перш за все розвивати загальну музикальність, музичний слух, виховувати внутрішній i вокальний слух, розвивати навички самоконтролю виконавця.

Виконання вокальних вправ слід проводити спочатку з постійним супроводом інструменту, потім чергувати спів із супроводом і без нього, а пізніше зняти супровід зовсім. Такий прийом підвищить відчуття відповідальності та самоконтроль співака.

Можна також рекомендувати виконавцеві (учню) заздалегідь уявити (ніби заздалегідь почути) звук, націлюючись на нього. Це активізує слух учня та його прагнення точності інтонування. Особливо важливою при цьому є точна атака першого звуку фрази. Тобто звук потрібно брати відразу, приблизно так, як це робить піаніст, коли він легко б'є по клавішах фортепіано. Якщо звук взято на гарній опорі (правильне співвідношення між натягненням голосових зв'язок та силою підзв'язкового тиску, яке легко досягається під час використання нижньореберного діафрагмального дихання), інтонаційно чисто, то співаку потрібно зберегти установку першого звуку на всій фразі. Це формується поступово, починаючи 3 простих вправ.

Горловий призвук доволі часто з'являється в результаті неправильного розуміння сутності опори звуку. Здається, що горло стиснуто, і звук ніби вижимається, із зусиллям проходячи через гортань, тобто виконавець шукає опору звуку через напруження м’язів. Під час правильної роботи гортані створюється враження, що у виконавця широко відкрите горло, i звук йде, ніби нічого на шляху не зачіпаючи.

Зазначений недолік є найтиповішим недоліком початкового етапу навчання, який з'являється у дітей. Голос дитини за відсутності слухової і вокальної координації не може перейти із мовленнєвого режиму в співацький. Горловий звук утворюється внаслідок напруженості, малорухливості, скутості нижньої щелепи. За такого положення гортань опиняється у неприродно високому положенні.

Для виправлення цього недоліку вчитель повинен запропонувати полегшений спів на голосні «У» та «О», які сприяють підняттю м’якого піднебіння, добре організовують позіх, допомагають округлити звук. А також варто співати, використовуючи придихову атаку, тобто приєднувати до голосної на кожному звуку приголосної «Х». Однак варто зважати на те, що придихову атаку слід використовувати тільки на початковому етапі роботи, поступово переходячи на м'яку атаку, яка також сприятиме зняттю скутості та горлового звучання. Водночас для звільнення голосового апарату від скутості необхідно на певний час відмовитись від розспівок на голосну «І», яка піднімає гортань і сприяє скутості. 
Гугнявість $є$ дуже неприємним для слуху дефектом. Він є наслідком або захворювань (тоді потрібно звертатися за медичною допомогою), або наслідком поганих співацьких навичок, результатом млявої, низько опущеної піднебінної завіси. За такого іiі положення звук часто проходить через ніс, набуваючи гугнявого відтінку.

Для усунення цього дефекту достатньо припідняти піднебінну завісу. Підняття можна досягти через зоровий контроль дивлячись у дзеркало, широко розкриваючи рот та глотку. Проаналізувавши це відчуття, відтворити звук на голосну «У» або «О», які достатньо піднімають м'яке піднебіння, наводять на відчуття позіху. Губи при цьому повинні бути активно включені в роботу, рот добре розкритий. Внаслідок таких вправ піднебінна завіса значно скорочується та усувається гугнявість.

Відкритим (білим, пласким) звуком доволі часто страждають не лише окремі співаки, а й хорові колективи. Щодо зазначеного недоліку T. Ластовецька пише, що таке «пласке» та напружене звучання зумовлене відсутністю елементів «прикриття», що спонукає голосниці працювати 3 «пересмиком», зі скутістю. Автор наголошує, що в академічній манері таке звучання не дозволяється ${ }^{8}$. Звернемо увагу, що спів відкритим (білим) звуком $\epsilon$ результатом використання розмовної артикуляції, висунення на перший план слова на шкоду звукоутворенню, відсутністю вирівняного, єдиного потоку специфічних співацьких голосних.

Спроба штучного наближення голосних, тобто їхне формування тільки в передній частині порожнини рота, без включення в роботу порожнини глотки, також дає в результаті не лише антихудожній «відкритий», але й до того ж затиснутий звук.

Варто наголосити, що зазначений недолік у звучанні дитячих голосів часто з'являється внаслідок хибного уявлення про яскравість звучання.

Відкритий звук $є$ надзвичайно бідним за забарвленням, низьким позиційно, негнучким, часто межує з криком, особливо на верхніх нотах. Нюанс piano під час співу відкритим звуком надзвичайно ускладнений і зазвичай знімається з дихання.

3 цим недоліком вчителю можна боротися, використовуючи прийом співу закритим ротом та на голосні «О» $\mathrm{i}$ «У», які за своєю природою звучать прикрито, а також за допомогою високої установки звуку (висока позиція).

Ще одним недоліком є тремоляція та качання звуку, які можна назвати найбільш важкими дефектами у звучанні голосу, оскільки не завжди можна встановити причину їх появи.

Педагогічна практика свідчить про те, що тремоляція та качання можуть бути пов'язані не лише з органічним обмеженням, вони можуть

\footnotetext{
8 Ластовенко Т. Специфіка формування вокальної техніки: ознаки недосконалості та особливості їх усунення. Педагогічні науки: теорія, історія, інноваційні технологіï. 2017. № 4 (68). С. 194. 
бути пов'язані $з$ дефектами в утворенні вібрато. Нерідко вони бувають результатом постійного форсування звуку та неправильного дихання.

Для 3'ясування причини цього недоліку вчителю потрібно передусім зняти надмірне напруження, запропонувати учню співати не голосніше $m f$, потім перевірити його дихання і розпочинати тренування рівного, без поштовхів, видиху. 3 голосних краще всього сприяють виправленню качання і тремоляції голосні «У» та «О».

Досліджуючи особливості інтонування та слухового контролю в естрадному співі, О.П. Сметана та Т.А. Паламарчук зазначають, що для оцінки інтонації вирішальне значення має концентрація звукового рівня, якщо вібрато організується в голосовому апараті так, що ми чуємо визначену висоту, то навіть перебільшена амплітуда його вібраційного коливання буде сприйматися достатньо естетично. Якщо ж звуковисотний рівень локалізується, тоді навіть невеликий розмах голосової вібрації буде сприйматися як надмірне «качання», тремоляція. За словами авторів, тремоляція звука сприймається на слух як вібрація з підвищеною амплітудою. Для їх виправлення потрібна стабілізація звуку і дихання за допомогою довготривалих спеціальних вправ у середній теситурі невеликим м'яким звуком'

Млявий звук та під'їжджання. Ці два недоліки часто супроводжують один одного. Однак один з них (під'їжджання) може бути під час будьякого звуку, як млявого, так і активного, оскільки є наслідком поганої звички, хибного уявлення про кантилену чи гонитвою за дешевим ефектом. Під’їжджання полягає в тому, що виконавець, починаючи співати, не попадає відразу в потрібний тон, а бере спочатку дещо нижче і тільки потім через glissando вирівнює звук до потрібної висоти.

Мляве звучання залежить від поганого дихання, від відсутності у виконавця розвинутої виконавської волі, від остраху (нерішучості) та загальної млявості характеру, від недостатньої цілеспрямованості. В останніх випадках з млявістю боротися досить важко, і тут багато чого залежить від співака.

Якщо млявий звук та під'їжджання відбуваються внаслідок недостатньої активності дихання, потрібно застосовувати такі прийоми: тверду атаку, спів вправ на staccato, а потім, по черзі з legato, виконання творів у швидкому темпі з гострою ритмікою, які активізують слух та увагу.

\section{ВИСНОВКИ}

У процесі навчання дітей вокальному мистецтву вирішується головне завдання художньо-естетичного виховання - становлення творчо активної особистості, здатної сприймати й оцінювати прекрасне в

\footnotetext{
${ }^{9}$ Сметана О.П., Паламарчук Т.А. Особливості інтонування та слухового контролю в естрадному співі: інтонаційний еталон артиста-вокаліста. Scientific Journal Virtus. 2017. № 16. С. 93.
} 
оточуючому світі, відчувати потребу в естетичній діяльності, перетворенні дійсності за законами краси.

Для виконання поставлених завдань у загальноосвітніх школах та в закладах позашкільної освіти вчителям (педагогам) потрібно зважати на вікові особливості розвитку дитячого голосу. Зазначене пов'язане не лише 3 тим, що фізіологічно дитячий організм перебуває в процесі формування, а й з тим, що це впливає на вокальні можливості.

Окреслене в цьому дослідженні дає підстави висновувати, що виховання, розвиток і охорона дитячого голосу є важливою в навчанні співу у сучасній системі освіти.

На уроках співу (вокалу, в хоровому класі) учень отримує основні вокальні навички, які дозволяють йому проспівати пісню чисто, струнко і виразно, сприяють охороні його голосу, виховують та розвивають у дитячому голосі, притаманні йому дзвінкість, наспівність і польотність.

Вокальні навички, отримані в дитячому віці, зберігаються у зрілому віці та мають велике значення не лише для співу, а й для розмовної мови.

Правильно організоване і проведене навчання співу 3 дитинства, яке зберігає голосовий апарат дітей здоровим, не тільки є можливим, але й необхідним, оскільки воно забезпечує нормальний розвиток співацької функції. Водночас варто зважати, що розвиток співацького голосу не $\epsilon$ самоціллю, а $є$ створенням здорового фундаменту для повноцінного масового музично-естетичного виховання підростаючого покоління.

Особливу увагу приділено питанням, пов'язаним 3 недоліками звукоутворення, їхніми можливими причинами та шляхам, методам i прийомам їх усунення. Окреслене дає можливість висновувати, що увесь навчальний процес має відбуватися тільки під контролем вчителя, який повинен дуже тонко реагувати на усі можливі відхилення від визнаних еталонів співу. Відтак $є$ розуміння того, що вчитель повинен бути озброєний не лише знаннями і музичними (вокальними) вміннями, а й відповідними методичними знаннями і практичними вміннями роботи 3 дитячими голосами на різних вікових етапах їх розвитку.

\section{АНОТАЦІЯ}

У роботі окреслено основні вікові особливості дитячого співацького голосу та визначено етапи його формування. Визначено особливості роботи гортані, дихання, артикуляційного апарату тощо. Наведено приклади вокальних вправ (розспівок), які варто використовувати на уроках вокалу (музики, в хоровому класі). Окрему увагу зосереджено на визначенні i характеристиці акустичних властивостей дитячого вокального мовлення. Проаналізовано основні недоліки звукоутворення у дітей, а також визначено методичні прийоми для усунення відповідних недоліків. 


\section{ЛІТЕРАТУРА}

1. Черкасов В. Вокально-хорова робота на уроках музичного мистецтва як засіб формування естетичної культури учнів загальноосвітніх навчальних закладів. Наукові записки [Кіровоградського державного педагогічного університету імені Володимира Винниченка]. Сер.: Педагогічні науки. 2012. Вип. 103. С. 9-17.

2. Липа I., Черсак О. Підготовка майбутнього вчителя до педагогічного керівництва співацьким розвитком молодших школярів. Збірник науково-методичних праць кафедри педагогіки початкової освіти Педагогічного факультету Прикарпатського начіонального університету імені Василя Стефаника. 2019. Вип. 3. С. 10-14.

3. Шаповалова Р.Г. Навчання сольному співу: голосоутворення та його структурні компоненти. Освітологічний дискурс. 2015. № 1 (9). C. $239-249$.

4. Ятло Л.Г., Ятло Л.П. Сівацьке дихання як основа вокально-хорової техніки дитячого хору. Збірник наукових пращь Уманського держсавного педагогічного університету. 2007. № 2. URL: http://znp.udpu.edu.ua/ article/view/187651.

5. Данільчишин Ю.М. Акустика голосового апарату й акустична будова голосу. Культура України. 2014. Вип.46. С. 275-282.

6. Прядко О.М. Акустичні особливості розвитку співацького голосу. Педагогічні науки: теорія, історія, інноваџійні технології. 2010. № 7 (9). C. $400-409$.

7. Бордулін В.Т., Штепа Ж.В. Основи вокальної майстерності. Сучасні інформаційні технології та інновачійні методики навчання в підготовиі фахівиів: методологія, теорія, досвід, проблеми. 2012. № 30. С. 306-309.

8. Ластовенко Т. Специфіка формування вокальної техніки: ознаки недосконалості та особливості їх усунення. Педагогічні науки: теорія, історія, інноваиійні технології. 2017. № 4 (68). С. 189-199.

9. Сметана О.П., Паламарчук Т.А. Особливості інтонування та слухового контролю в естрадному співі: інтонаційний еталон артиставокаліста. Scientific Journal Virtus.2017. № 16. C. 90-94.

\section{Information about author: Mozhaikina N. S.,}

$\mathrm{PhD}$ in Pedagogy, Associate Professor, Professor at the Department of Theory and Methods of Voice Production National Pedagogical Dragomanov University

9, Pyrohova str., Kyiv, 01601, Ukraine 